\title{
New Measurement Method of Outgassing Speed with a Sealed off Residual Gas Analyzer Fumio WATANABE
}

Vaclab Inc., SOHO103, 2-1-2 Matsushiro-Tsukuba, 305-0035, Japan

(Received August 1, 2007, Accepted June 7, 2008)

\begin{abstract}
The new measurement method of outgassing speed with a sealed off quadrupole residual gas analyzer (RGA) has been proposed. The unique feature of this method is that the high vacuum can be maintained by the self-pumping effect of the ultra low outgassing RGA. The newly-developed mass analyzer combined with BA-gauge is the key for this method. The pressure of chamber can be maintained below $2 \sim 5 \times 10^{-7} \mathrm{~Pa}$ for a year without any pumping system. The majority of residual gases in the chamber were found to be hydrogen, methane and carbon-monoxide. In order to measure the outgassing speed of the RGA, the pumping speeds were measured by the self-pumping effect of RGA for hydrogen, deuterium, methane, nitrogen, carbon-monoxide, carbon-dioxide, oxygen and argon. When the pumping speed of RGA is balanced for outgassing from the RGA itself, we can calculate its value from the partial pressure in the spectrum. Then, we obtain the outgassing speeds for hydrogen $=8.8 \times 10^{-13} \mathrm{~Pa} \mathrm{~m}^{3} / \mathrm{s}$, methane $=1.2 \times 10^{-13} \mathrm{~Pa} \mathrm{~m}^{3} / \mathrm{s}$, carbonmonoxide $=1.0 \times 10^{-13} \mathrm{~Pa} \mathrm{~m}^{3} / \mathrm{s}$.
\end{abstract}

\section{1. はじめに}

フラットパネルディスプレイ（FPD）や微少機械技術 (MEMS) などの先端技術分野でも真空技術は使われる．シ ステムはゲッターだけで真空を維持する必要があり，ゲッ ター以外のポンプを使わない永久封止真空システムであるこ とが多い. 封止真空技術の多くは, 電子管やブラウン管時代 （20世紀）に多くの技術開発がなされ，ほぼ完結している. しかし, 超薄型大面積の FPD や極微少空間の MEMS の封 止真空となると別で, 新たな課題が発生してくる. 一定空間 に蓄積されるガス圧力は, ガス放出速度が一定であれば表面 積 $\left(\mathrm{r}^{2}\right)$ に比例し, 体積 $\left(\mathrm{r}^{3}\right)$ に反比例する. 即ち, 表面積/ 体積 $=1 / \mathrm{r}$ であるから， r (球の半径）が小さくなればなる ほど相対的に表面積の割合が増し，その結果 FPD や MEMS を構成する材料に要求されるガス放出速度は, 超高 真空を越えて極高真空のレベルになる.このような新しい分 野の真空技術開発には, 残留ガス分析計（Residual Gas Analyzer，RGA）が欠かせない。ところが，従来の RGAの 多くは, 分析計自体からのガス放出が大きく, 極高真空を発 生させるとなると大排気量のポンプを備え付けた真空システ ムを準備しなければならない。このため，FPD や MEMS から懸け離れた真空システムを用いて技術開発を行うことに なり, サンプルから放出される微少なガス成分は, システム のバックグランドガスに埋もれて排気されてしまい, 検出不 可能である.

システムの真空 $P$ は, $P=Q / S(Q$ : ガス放出速度, $S:$ 排 気速度) で与えられるから，FPD や MEMS などの場合は， $Q, S$ 共に極限まで小さくした真空システムで実験した方が 目的に合致した結果が得られる。排気速度 $S$ を極限まで小

*2007年 3 月 第54回応用物理学関係連合講演会極高真空シン ポジウムにて一部講演

*1 有限会社 真空実験室（テ305-0035 茨城県つくば市松代 210-2, SOHO103)
さくすると, RGA 自身の持つ排気作用だけで真空を維持す る方法に到達する. これ以上小さい排気速度でのガス分析法 は存在しない。しかし，この方法を実現するためには，分析 計自体のガス放出は極限まで小さくする必要がある.

最近開発された「BA 電離真空計複合型超低ガス放出四重 極残留ガス分析計」(Total pressure measurable ultra-low outgassing quadrupole residual gas analyzer, 略称 TULORGA (テュロアールジーエ) ${ }^{1)}$ は, ガス放出速度が従来の RGA に比べて $1 / 10000$ 程度まで小さく2), さらに $10^{-8} \mathrm{~Pa}$ ま での全圧測定が可能なので, この封止残留ガス分析計（以 下，封止 RGA）に適している. 本報は, 封止 RGA を用い て, 気体別のガス放出速度測定を求める新しいガス放出速度 測定法を提案するものである.

\section{RGA の排気速度の測定}

RGA や電離真空計の排気速度は, Fig. 1 の様なシステム を使って求めることができる. 容積 $V$ の真空容器に試料力゙ スを $P_{0}$ まで導入し, これを排気速度 $S$ のポンプで減圧する ときの圧力 $P$ の変化は次式で示される.

$$
P=P_{0} \exp (-S / V \cdot \Delta t)
$$

ここで $P_{0}=$ 初期圧力 $(\mathrm{Pa}), S=$ 排気速度 $\left(\mathrm{m}^{3} / \mathrm{s}\right), V=$ 容器 の体積 $\left(\mathrm{m}^{3}\right), \Delta t=$ 排気時間 $(\mathrm{s})$ である. 試料ガスのマス スペクトルのイオン電流強度を $I$ とすると

$I=k \cdot P$ 及び $I_{0}=k \cdot P_{0}(k$ は感度係数）であるから， これを式(1)に代入すると

$$
I=I_{0} \exp (-S / V \cdot \Delta t) \text { が得られる. }
$$

即ち,

$$
\text { In } I=-S / V \cdot \Delta t+\operatorname{In} I_{0}
$$

となり, イオン電流の変化から排気速度 $S$ を求めることが できる。

測定に用いたシステムFig. 1 の真空容器は, ICF $114 \times 2$ $+\mathrm{ICF} 070 \times 4$ を有する $0.2 \% \mathrm{BeCu}$ 合金製である。これにス ピニングローターゲージ $(\mathrm{SRG})$, エクストラクター型電離 
真空計 $(\mathrm{EXG})$, 試験 RGA (ULO-RGA) 3) が取り付けられ ている. また, ガス導入用オールメタルリークバルブ (LV) を介して試料ガスボンべが繋がれている。排気は ICF114 オールメタルアングルバルブ $(\mathrm{AV})$ を介して磁気浮上ター ボ分子ポンプ (TMP) +ダイヤフラム (DP) で行った. 真 空容器, SRG, EXG, ULO-RGA を含む全容積を求めるため に, ミニオールメタルバルブ（MV）を介して標準容器 $a$ $\left(7.56 \times 10^{-6} \mathrm{~m}^{3}\right)$ が接続されている. 全容積 $V$ は, 標準容 積 $a$ に溜めたアルゴンガスを $V$ に膨張させて, ボイルの法 則を使って求められる. この測定は， $0.1 \sim 1 \mathrm{~Pa}$ の比較的圧 力の高い領域で $\mathrm{SRG}$ の圧力変化から求めることができる. 測定に用いたシステムの全容積は $V=1.23 \times 10^{-3} \mathrm{~m}^{3}$ であっ た。 また，排気速度を求めた ULO-RGA は，Fig. 2 のBA 真空計に相当する BA 針が無い旧タイプの構造を有する低ガ ス放出 RGA であるが, 機能は Fig. 2 の TULO-RGA に全 く同じである. Fig. 2 のコバールガラスの誢き空を外し，こ のフランジ部分をFig. 1 の真空容器に接続した.

実際の排気速度の測定は, AV を開けてベーキング脱ガス 排気を行った後, 室温において, AV を閉じて試料ガス（純 ガス $99.9 \%$ ）を LVの調整により $10^{-3} \mathrm{~Pa}$ 台まで導入し，こ こから排気を開始した. ガス導入時の圧力 $P_{0}$ は, ガス放 出, 排気作用が共に無視できる SRG で測定し, EXG は消 灯して用いなかった．この状態から RGAのフィラメントを 点灯すると, 圧力降下が始まった. 圧力降下は試料ガスのマ ススペクトルデータをパーソナルコンピュータに取り込み, この記録から排気速度 $S$ を求めた。式 (2)より, 横軸に時間 $t$ を, 縦軸にスペクトルの電流強度の対数 In $I$ を採った時,

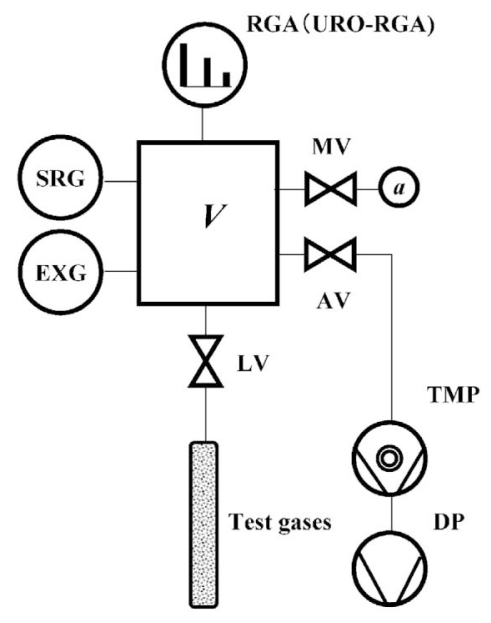

Fig. 1 Measurement system of a pumping speed of RGA (ULO-RGA.)
圧力降下は直線であり, その傾きが排気速度 $S$ になる。排 気を続けると, 途中から圧力降下が緩やかになり（直線から 外れ), 最終的にある值から下がらなくなった。これは排気 された試料ガスの再放出があるためであるが, 試料ガスと同 じ種類のガス放出が測定システムからもある場合は，これが 加算される.

この方法によって求めた試料ガスは, 水素, 重水素, メタ ン, 窒素, 一酸化炭素, 酸素, 二酸化炭素, アルゴンの 8 種類で，その結果を Table I に示す．ガスの種類によって $\Delta t$ が異なるのは, 圧力降下時の直線維持時間の最大值で排 気速度 $S$ を求めたことによる. 本測定で, ガスの種類を替 える時は, ガスボンべを交換後, ガス供給ラインおよび LV を含む真空システム全体のガスの入れ替えを数回繰り返し, さらに十分なシステムベーキング脱ガス排気を行った. また, RGAのグリッドには $1000^{\circ} \mathrm{C}$ 通電脱ガスと電子衝撃脱ガス を行い，前の試料ガスの影響を受けないように注意した．各 ガスの圧力降下の特徵は次のようであった.

水素 $\left(\mathrm{H}_{2}\right)$ : 排気開始から 2 桁下がった比較的高い圧力の $10^{-5} \mathrm{~Pa}$ から排気による圧力降下が無くなった。これは RGA 全体から放出される水素のガス放出と, RGAの排気 が平衡に達した為である.これ以下の水素圧力に対しても排

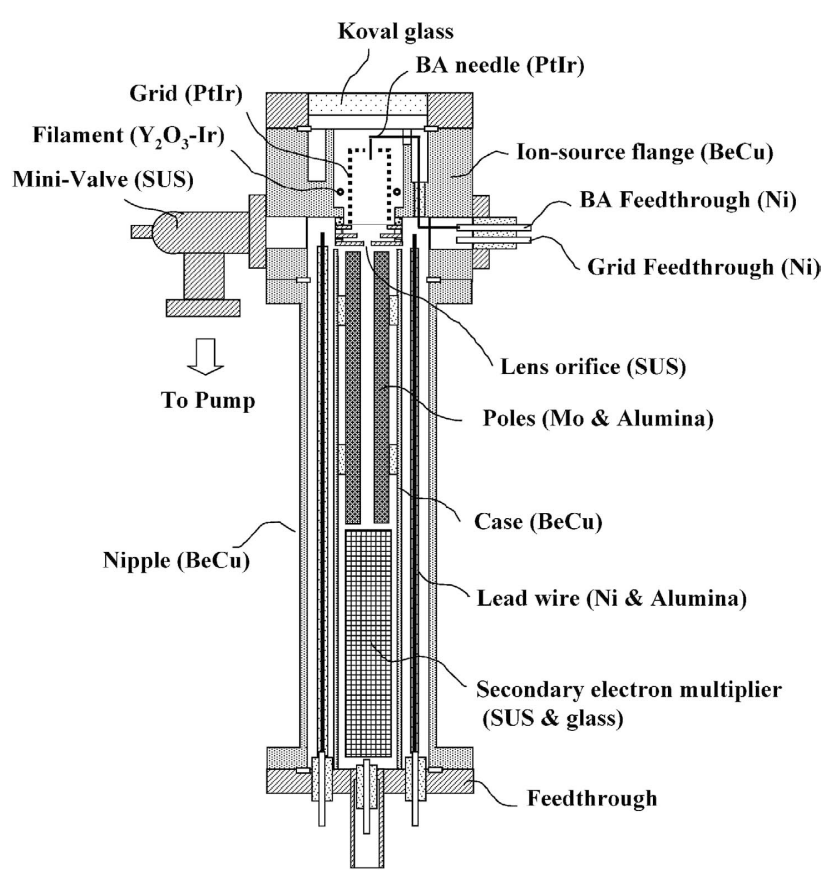

Fig. 2 Cross section of a BA gauge combined with an ultralow outgassing quadrupole residual gas analyzer (TULORGA100).

Table I Measurement Result of Pumping Speed of URO-RGA for 8 kinds of gases

\begin{tabular}{l|c|c|c|c|c|c|c|c}
\hline \hline \multicolumn{1}{c|}{ Substance } & $\begin{array}{c}\text { Hydrogen } \\
\mathrm{H}_{2}\end{array}$ & $\begin{array}{c}\text { Deuterium } \\
\mathrm{D}_{2}\end{array}$ & $\begin{array}{c}\text { Nitrogen } \\
\mathrm{N}_{2}\end{array}$ & $\begin{array}{c}\text { Methane } \\
\mathrm{CH}_{4}\end{array}$ & $\begin{array}{c}\text { Carbon-monoxide } \\
\mathrm{CO}\end{array}$ & $\begin{array}{c}\text { Carbon-dioxide } \\
\mathrm{CO}_{2}\end{array}$ & $\begin{array}{c}\text { Oxygen } \\
\mathrm{O}_{2}\end{array}$ & $\begin{array}{c}\text { Argon } \\
\mathrm{Ar}\end{array}$ \\
\hline Pumping Speed $\times 10^{-6}\left(\mathrm{~m}^{3} / \mathrm{s}\right)$ & 6.7 & 6.7 & 2.9 & 6.1 & 2.7 & 21.0 & 71.5 & 0.063 \\
\hline Measurement time $\Delta t(\mathrm{~s})$ & 157 & 550 & 480 & 472 & 570 & 256 & 78 & 508 \\
\hline Initial Pressure $P_{0}\left(\times 10^{-3} \mathrm{~Pa}\right)$ & 5.1 & 4.4 & 1.0 & 0.9 & 3.9 & 3.3 & 7.4 & 0.9 \\
\hline
\end{tabular}


気作用を持つことを確認するために, 試料ガスを重水素 $\left(\mathrm{D}_{2}\right)$ に替えて, 重水素の排気速度測定も行った. 重水素の 場合は, さらに 2 桁低い $10^{-7} \mathrm{~Pa}$ 台の圧力まで直線的に降下 した. 重水素に対する排気曲線は $10^{-7} \mathrm{~Pa}$ 台まで直線であ り，その排気速度 $S$ は水素の值に完全に一致した，この結 果は, 次章で述べる封止ガス分析時の水素のピーク值が， $P$ $=10^{-7} \sim 10^{-3} \mathrm{~Pa}$ 間で封止平衡状態にある時, RGA の排気 速度 $S$ と RGA の水素ガス放出速度 $Q$ が, $P S=Q$ と等しい ことの根拠となった.

窒素 $\left(\mathrm{N}_{2}\right)$ : 排気が進むと $\mathrm{H}_{2}$ が放出されてくる非常に興 味深い現象が観察された。排気速度の $2.9 \times 10^{-6} \mathrm{~m}^{3} / \mathrm{s}$ は, エクストラクター型電離真空計の排気速度の約 $1 / 5$ とかな り小さい.

メタン $\left(\mathrm{CH}_{4}\right)$ : 重水素に近い排気曲線が得られた。同じ く排気が進むと $\mathrm{H}_{2}$ が放出されてきた.

一酸化炭素 (CO)：吸着による排気が約半分を占める (SRGの圧力変化で求めた). フィラメント点灯後の全排気 速度は $2.7 \times 10^{-6} \mathrm{~m}^{3} / \mathrm{s}$ と窒素とほぼ同じであるから, $m / z=$ 28 の CO のイオン化による排気速度は, 同じ $m / z=28$ の窒 素の約半分と考えて良い. 同じく排気が進むにつれて $\mathrm{H}_{2}$ が 放出されてきた.

二酸化炭素 $\left(\mathrm{CO}_{2}\right)$ : 壁の吸着による排気速度は一酸化炭 素と同じ程度であるが，イオン化による排気速度は非常大き い. 排気が進むと $\mathrm{H}_{2}$ に加えて $\mathrm{CO}$ も放出されてきた.

酸素 $\left(\mathrm{O}_{2}\right)$ : 吸着による排気速度が非常に大きく, $33 \times$ $10^{-6} \mathrm{~m}^{3} / \mathrm{s}$ もある. イオン化と吸着との合計の排気速度は 72 $\times 10^{-6} \mathrm{~m}^{3} / \mathrm{s}$ まで大きい. 排気が進むと $\mathrm{CO}$ が放出されてき た.

アルゴン $(\mathrm{Ar})$ : 非常に小さく窒素の $1 / 48$ だる.

\section{3. 封止 RGA の圧力変動とガス放出速度}

$\mathrm{RGA}$ 封止後の圧力変動とガス放出速度の測定に用いた TULO-RGA ${ }^{4}$ の断面を Fig. 2 に示す. RGA 封止後, グリ ッドの通電加熱時の温度を光学的手法で測定できるようにす るために, システムに接続する部分のフランジにコバールガ ラス製の䙼き空を付けた。この空は予め真空電気炉で $450^{\circ} \mathrm{C}$ $\times 24 \mathrm{~h}$ の脱ガス処理してあるものを用いた．排気は，イオ
ン源フランジの予備ポートに封じ切り用ミニメタルバルブを 接続し，ミニバルブを介して行った.このミニバルブにも， 予め $400^{\circ} \mathrm{C} \times 24 \mathrm{~h}$ の脱ガス処理を行った.

TULO-RGA は Fig. 2 の状態のままで超高真空排気シス

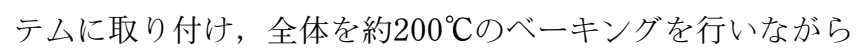
約 $6 \mathrm{~h}$ 排気した. またベーキング中は RGA のグリッドを通 電により $1000^{\circ} \mathrm{C}$ 加熱した. ベーキング終了後, $1000^{\circ} \mathrm{C}$ 通 電加熱に加えて電子衝撃脱ガス（200 V, $10 \mathrm{~mA}, 2 \mathrm{~min} ）$ を 3 回加算し, 脱ガス排気を終了した.この状態で $4 \sim 5$ 時間 室温に放置すると $2 \times 10^{-9} \mathrm{~Pa}$ の真空に到達した. 残留ガス 組成は $\mathrm{H}_{2}(90 \%)$ と $\mathrm{CO}(10 \%)$ の 2 種類で, それ以外のガ ススペクトルは観察できなかった．この状態からミニバルブ を閉じた. バルブ締め付けと同時に大量の $\mathrm{H}_{2}, \mathrm{CH}_{4}, \mathrm{CO}$ が 発生し， $10^{-5} \mathrm{~Pa}$ 台まで圧力は一挙に上昇した. その後, $\mathrm{CH}_{4}, \mathrm{CO}$ は時間経過と共に RGA の排気作用で減り, 2 時間 後 $2 \times 10^{-7} \mathrm{~Pa}$ で安定した（Fig. 3 とほぼ同じスペクトル状 態).その後は, TULO-RGA にミニバルブを付けた状態で 排気システムから外し, 約 1 年間この封止状態を続けた。 1 年間の温度環境は, 1 日の中では $10 \sim 20^{\circ} \mathrm{C}, 1$ 年間通して は, 夏の最大で $40^{\circ} \mathrm{C}$, 冬の最低では $4 \sim 5^{\circ} \mathrm{C}$ 程度の変動があ り，それに連動するように全圧は $10^{-7} \mathrm{~Pa}$ 台で変化した。

封止は2005年11月 3 日に実施した. それから 3 ヶ月経過 した2006年 2 月 6 日における残留スペクトルを Fig. 3 に示 す.この 3 ヶ月の間に, フィラメントの点灯と消灯を数十

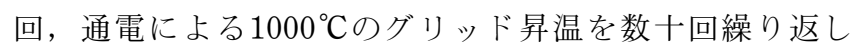
た. 点灯及びグリッドの $1000^{\circ} \mathrm{C}$ 昇温により, 一時的な圧力 の増大（10-4 $\mathrm{Pa}$ 台）が起こったが，5～6 時間経過すると 4 $\sim 5 \times 10^{-7} \mathrm{~Pa}$ の圧力まで下がった. 圧力上昇の主成分は $m /$ $z=2$ の $\mathrm{H}_{2}$ 之, $m / z=28$ の $\mathrm{CO}(m / z=12$ の C から判断）で あった。その後 2006 年 5 月 7 日から 2006 年 9 月 6 日までの 約 3 ヶ月間, フィラメントを消灯したままで室内に放置し た.この状態から, 再びフィラメントを点灯した直後のスペ

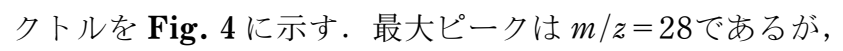
$\mathrm{N}$ の $m / z=14$ のピークと $\operatorname{Ar} の m / z=40$ のピークが観察され たので, 封止 TULO-RGAにリークが発生したと判断し た．その理由は，リークがあった場合，酸素はベーキングさ れた壁にほぼ100\%が吸着されて気相には現れないが，窒素

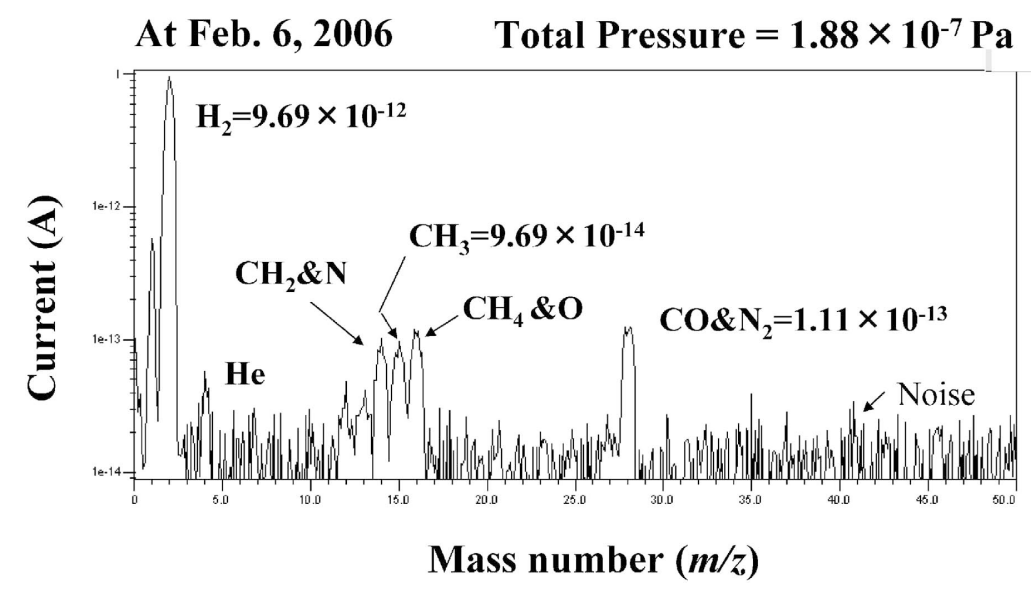

Fig. 3 Accumulated gas spectrum at three months after sealed off from a pumping system. 
は分子の形で残留ガス成分として残り，空気中に在る約 $1 \%$ のアルゴン $m / z=40$ も残留ガス成分に残ることによる。 そ のリーク量を概算してみると, 封止 RGAの容積 $V^{\prime}=0.36$ $\times 10^{-3} \mathrm{~m}^{3}, 3$ ヶ月間の上昇圧 $\Delta P=3 \times 10^{-4} \mathrm{~Pa}, 3$ ヶ月の経 過時間 $\Delta t=8 \times 10^{6} \mathrm{~s}$ として, $V \Delta P / \Delta t=1.4 \times 10^{-14} \mathrm{~Pa} \mathrm{~m}^{3} / \mathrm{s}$ と求まり極微少であった. しかし, Fig. 4 の状態から点灯を 1 週間続けると, $\mathrm{N}_{2}$ ガス $(m / z=14$ から判断 $)$ と, $\operatorname{Ar}(m / z$ =40）のピークはスペクトルからは消えた.このスペクト ルをFig. 5 に示す.

Fig. 4 のスペクトル状態はリークによる結果か否かを確か めるために, フィラメントを消灯し, 封止 RGA 全体（Fig. 2 の状態）をへリウムを満たしたプラスチックパックの中に 入れ， 2 週間放置してみた（時々ヘリウムは補充した）。 そ の後, 再点灯してみたがへリウムの増大は観察できなかっ た. 続いて点灯と消灯を $1 \sim 2$ 日毎に繰り返し見ると, Fig. 4 と Fig. 5 を繰り返すことが分かった.この動向から, 封 止後に RGA の排気作用によって排気される窒素, アルゴン は, 消灯時には再放出されるが, 連続点灯時には排気されて ピークとして現れないことが分かった. 従って, 点灯後平衡 圧に達した封止 RGA から得られるスペクトルは， RGA 内 に一定量のガス放出源が存在する結果として現れるスペクト ルであって, 突発的なガス放出（グリッドの加熱脱ガスやバ
ルブ封止時のガス放出など）や微少なリークによって蓄積し たガスなどの影響を受けないことが明らかになった. 本封止 実験終了直前（一年経過した時点）の平衡圧でのスペクトル をFig. 6 に示す.

この 1 年間の封止残留ガス分析の結果から明らかなよう に, TULO-RGA をべーキング排気した後, 封止して得られ た数時間後の平衡状態は, TULO-RGA のバックグランドガ ス放出であり，そのガス成分は $\mathrm{H}_{2}, \mathrm{CH}_{4}, \mathrm{CO} の 3$ 種類であ ることが分かった．その值は次のようなる.

Fig. 3 のスペクトル強度から,

$$
\begin{aligned}
& I_{\mathrm{H} 2}=9.69 \times 10^{-12} \mathrm{~A}, I_{\mathrm{CH} 3}=9.69 \times 10^{-14} \mathrm{~A}, \\
& I_{\mathrm{CO}}=1.11 \times 10^{-13} \mathrm{~A}
\end{aligned}
$$

である.これをTULO-RGAを稼動させるソフト Tware $32^{5}$ により, 窒素換算圧の分圧強度に変換すると,

$$
\mathrm{H}_{2}=70.5 \%, \mathrm{CH}_{4}=9.3 \%, \mathrm{CO}=20.3 \%
$$

となる.ここで, $\mathrm{CH}_{4}(\mathrm{~m}=16)$ は, $\mathrm{ESD} の \mathrm{O}(\mathrm{m}=16), \mathrm{CO}$ からのクラッキング $\mathrm{O}$ 原子 $(\mathrm{m}=16)$ と重複するので, $\mathrm{CH}_{3}(\mathrm{~m}=15)$ の強度で求め, $\mathrm{CH}_{4}$ の $\mathrm{CH}_{3}$ のクラッキングパ ター係数 0.86 を使って算出した.

TULO-RGA の内蔵 BA 真空計による窒素換算全圧は 1.88 $\times 10^{-7} \mathrm{~Pa}$ であるから，これより残留ガス分圧は，

$P_{\mathrm{H} 2}=1.32 \times 10^{-7} \mathrm{~Pa}, P_{\mathrm{CH} 4}=2.03 \times 10^{-8} \mathrm{~Pa}, P_{\mathrm{CO}}=3.81$

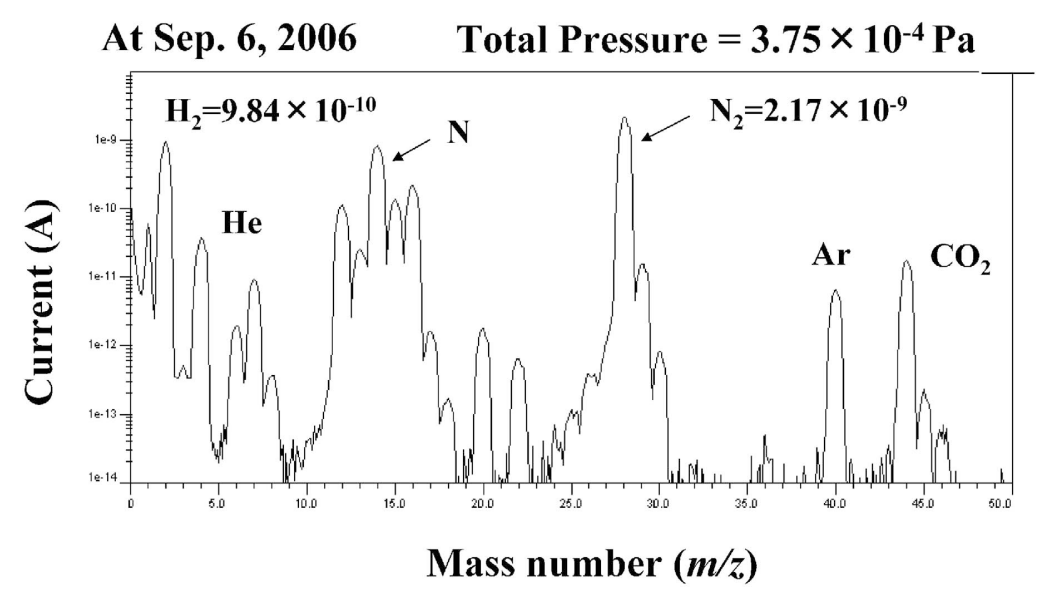

Fig. 4 Accumulated gas spectrum through three months without any operation.

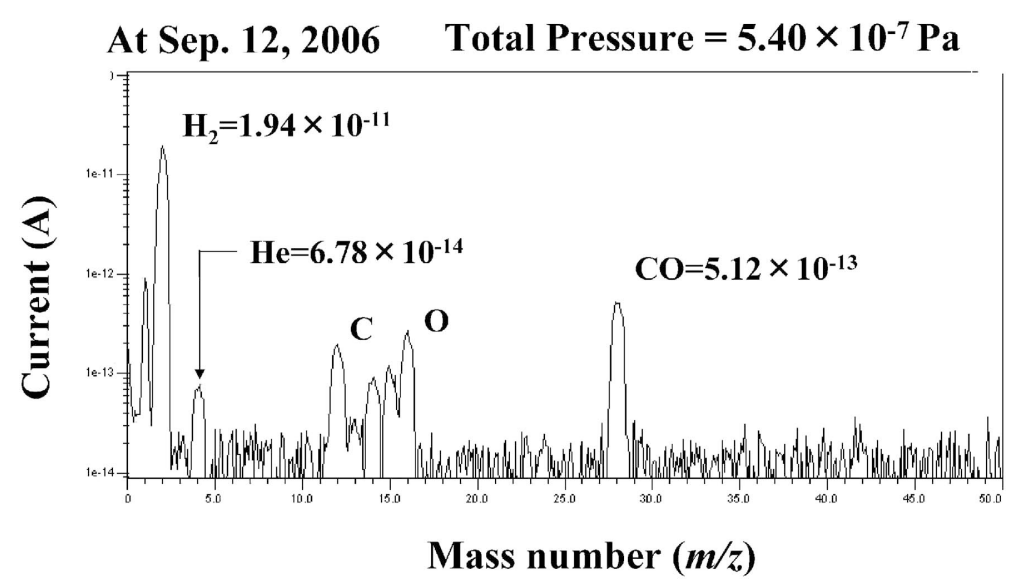

Fig. 5 Accumulated gas spectrum after a week from Fig. 4 with filament on. 


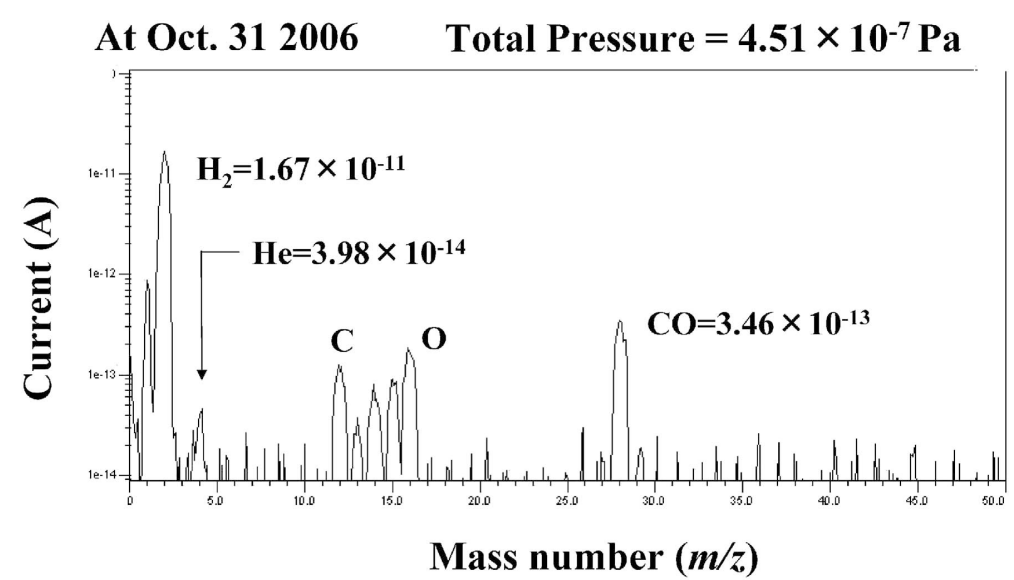

Fig. 6 Accumulated gas spectrum after about one year the sealed off from a pumping system.

$\times 10^{-8} \mathrm{~Pa}$

となる.この結果と Table I の結果を， $Q=S P$ の式に代入 して各気体別のガス放出速度を求めると

$Q_{\mathrm{H} 2}=8.8 \times 10^{-13} \mathrm{~Pa} \mathrm{~m}^{3} / \mathrm{s}, Q_{\mathrm{CH} 4}=1.2 \times 10^{-13} \mathrm{~Pa} \mathrm{~m}^{3} / \mathrm{s}$, $Q_{\mathrm{CO}}=1.0 \times 10^{-13} \mathrm{~Pa} \mathrm{~m}^{3} / \mathrm{s}$

が得られる．これが TULO-RGA の気体別バックグランド ガス放出速度である.

\section{4. 新しいガス放出速度測定法の提案}

封止残留ガス分析法で求めた TULO-RGAの 3 種類のガ ス放出速度は, 熱陰極フィラメント, グリッド, イオン源フ ランジ, 四重極, 2 次電子増倍管, 内外 $2 つ 0$ 外筒管, リー ド線, 真空端子など, 多くの金属とセラミック部品から放出 された集積分圧に, 別の同等機種 (ULO-RGA) から得たガ 又種別排気速度を乗じて求めた值であるから, TULO-RGA の真のガス放出速度とは多少異なる.しかし, 本試験を含め 繰り返した幾多の実験では, $200^{\circ} \mathrm{C} \times 6 \mathrm{~h}$ 程度のシステム ベーキングを行った後, グリッドに $1000^{\circ} \mathrm{C}$ 程度での通電加 熱を行い, さらに電子衝撃加熱を加えれば, 確実に $10^{-9} \mathrm{~Pa}$ 台のシステム到達圧が得られ, バルブ封止すれば, Fig. 3 の スペクトルが得られる. 従って, 上に列記した程度以上のガ ス放出速度を有するサンプル（小型真空容器や微少ガス源素 子）であれば, TULO-RGA にサンプルを接続し, サンプル のガス放出率（表面積が明らかな場合）測定が可能になる.

このような考察に基づき, 新しいガス放出速度計測システ ムとして, Fig. 7 の様な構成を本報において提案する.こ のシステムでは, サンプルが直径 $100 \mathrm{~mm}$, 長さ $130 \mathrm{~mm}$ 程 度の容積約 1 リットルの円筒状真空容器だった場合, 表面 積は $0.056 \mathrm{~m}^{2}$ になるから, $10^{-13} \mathrm{~Pa} \mathrm{~m}^{3} / \mathrm{s} \div 0.056 \mathrm{~m}^{2}=\sim 2 \times$ $10^{-11} \mathrm{~Pa} \mathrm{~m} / \mathrm{s}$ 程度までのガス放出率を求めることができ る. 本封止 RGA ガス放出速度測定法で求めた TULO-RGA の $10^{-13} \mathrm{~Pa} \mathrm{~m}^{3} / \mathrm{s}$ 台の水素ガス放出速度は, ベーキング条 件, グリッドの脱ガス条件によって多少変化すると思われる が, RGAの排気作用による気体別排気速度は比較的に安定 であり，RGAの “その場ガス放出速度”さえ正確に求めら れれば，本封止 RGA ガス放出速度測定法の精度は高められ る. 例えば Fig. 7 に示したように, サンプルと RGA の間に

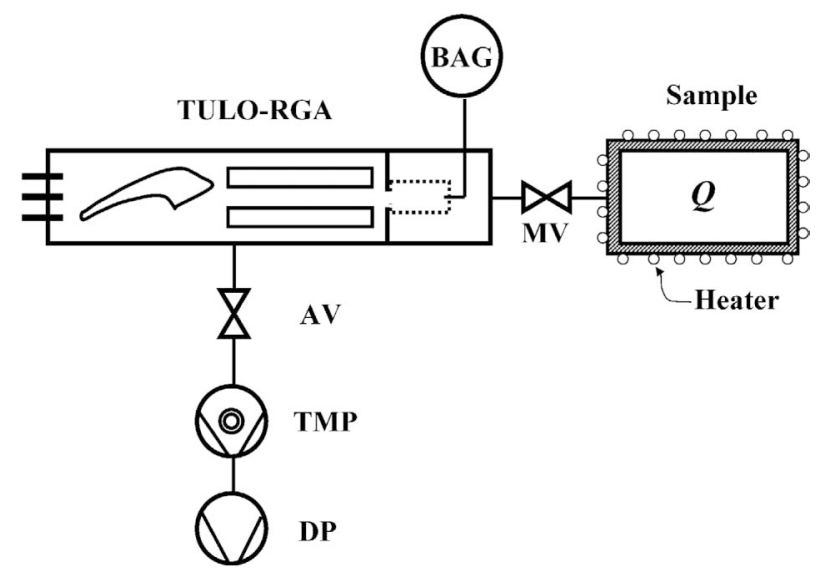

Fig. 7 Example system of the new gas analysis and outgassing rate measurement from a sample.

遮断バルブ MV を入れ, 測定前にバルブ MVを閉じ, $\mathrm{RGA}$ の “その場ガス放出速度”を求めて打き，その後に AV と MVの両バルブを開け，十分に排気を続けて安定化させる. 次に, AV を閉じて得られる全ガス放出速度から“その場ガ ス放出速度”を差し引けば, サンプルの真のガス放出速度が 求められる.

また, Fig. 7 のシステムでは, サンプルの温度をサンプル の外に巻いた電熱線加熱により $0.5^{\circ} \mathrm{C} / \mathrm{s} \sim 1^{\circ} \mathrm{C} / \mathrm{s}$ 程度の昇温速 度で上昇させれば (AVは開)，サンプルの昇温脱離測定も 行うことが可能である ${ }^{6)}$. 更に温度 $T$ をパラメータとしたス ペクトル強度を $\Delta Q(T)=\Delta P(T) S$ として求め, アレニウス プロットから外挿法を使って室温における值を推測すること も可能である. この手法を用いれば， $10^{-12} \mathrm{~Pa} \mathrm{~m} / \mathrm{s}$ 台の極 高真空向け材料のガス放出率も測定可能である.これまでの 超高および極高真空向け材料のガス放出率測定は, スループ ット法か SRG を用いるビルドアップ法しかなく, 前者は測 定系からのガス放出とポンプ作用の影響が無視できないし, 後者は水素に限られる上, 水素吸着サイトに水素が飽和吸着 するまで $(0.2 \% \mathrm{BeCu}$ の場合，最低でも 3 週間 $)$ 待たなけ ればならない6). どちらも大がかりなシステムと, 時間, 労 力が必要である。これに対して，RGAのポンプ作用を使っ 
てガス放出を求める本報の封止 RGA ガス放出速度測定法 は, 動的状態で複数のガス種に対してのガス放出速度（率） を，小サンプルを用いて簡単に求めることができる.

\section{5. 考察}

封止 RGA を用いてサンプルのガス放出速度を測定する本 提案は, 予め理論立てて系統的に実験を行ったのではなく, 低ガス放出 RGA を封止して長期間動作させる機会が有り, 試したところ動作時の圧力が $10^{-7} \mathrm{~Pa}$ 台を保持できることか ら考案されたものである. また, 本報に載せた 8 種類の気 体に対する RGA の排気速度も, 本封止 RGA ガス放出速度 測定法のために新たに測定されたデータではなく，別の機会 に得ていたデータを活用したものである．このため，水とへ リウムのデータは無い. 従って, この新しい封止 RGA ガス 放出速度測定法を用いてサンプルのガス放出速度測定を行う 場合は，使用する RGAの排気速度を改めて測定する必要が ある.しかし, Table I に示した排気速度は, TULO-RGA の前の機種（ULO-RGA）から得た值ではあるが，TULORGA とULO-RGA との違いは, 全圧測定用のBA 真空計 （白金イリジウム合金の細針 ${ }^{\phi} 0.2 \mathrm{~mm}, \mathrm{~L} 3 \mathrm{~mm}$ ) が付いてい るか否かだけで, グリッド材やフィラメントなど, イオン源 の構成は全く同等であり, 電気的動作条件も同じなので, TULO-RGA と ULO-RGA との排気速度の差は殆ど無く, そのまま適用できると判断した。

メタンは, 金属酸化物表面の触媒作用によりバルク内の水 素々表面の炭素が反応して発生していると考えられるが，こ れまでのガス放出速度測定法であるスループット法とビルド アップ法では測定が困難であり，材料評価項目から外されて いたガス種である. 本封止 RGA ガス放出速度測定法では, 放出されてくるメタンガスも極高真空構造材の材料評価の対 象ガス種に加える必要があることを示唆している。

一酸化炭素については, グリッドの温度を上昇させるとそ の強度が増大することから, RGA グリッドからの電子刺激 脱離分子（ESD）であると思われるが，100\%がグリッドか らであるかどうかはこの方法だけでは判別出来ない。ただ, イオンポンプで排気する封止小型真空システムに ULORGA を付けて, イオンポンプのオン, オフを繰り返すと, $\mathrm{CO}$ のスペクトルだけが無反応であるから ${ }^{7)}, \mathrm{CO}$ は RGA グ リッドからの ESD と判断して良いと筆者は考えている.

最も重要である水に対する排気速度のデータが無いので, 水のガス放出のあるサンプルについては本封止 RGA ガス放 出速度測定法が適用出来るかどうかは不明である. 水は吸着
性が高く, ベーキング後の真空壁と化学反応も起こすので, 本封止 RGA ガス放出速度測定法は適用できないと筆者は考 えている.

Fig. 3〜Fig. 6 の何れのスペクトルにも $m / z=4$ のヘリ ウムのピークが現れている．このへリウムピークは RGAの 組立後のリーク試験時に混入するケースが殆どであるが, 残 留ガスとしては存在するので，ヘリウムに対する排気速度も 調べる必要がある. RGAのへリウムに対する排気速度は, アルゴンよりはさらに小さいと予想できるから，ヘリウムは 封止 RGA 中で殆ど排気されないと考えてよい。本封止 RGAのこの特異性を生かせば, ビルドアップ法による超高 感度のヘリウムリーク試験も可能になる。

\section{6. まとめ}

封止 RGA ガス放出速度測定法を用いて, $10^{-13} \mathrm{~Pa} \mathrm{~m}^{3} / \mathrm{s}$ 台の低ガス放出速度をガス種類別に測定することが可能であ ることを示し, 新しいガス放出速度測定法を提案した．この ガス放出速度測定法は, 水素やメタンなど吸着性の低いガス にしか適用できないが, 超高および極高真空に使われる材料 からのガス放出は, 正にこれら低吸着性のガスが問題なので あるから，それらの材料研究の道具として大変有用性の高い 計測法になると筆者は考えている.

本封止 RGA の別の使い方としては, 機能性ガラスに含ま れる極微少泡の破壊ガス分析, 新材料の極微少ガス透過試 験, 電子デバイスの劣化を起こす有害ガスの同定など, これ まであまり考えて来なかった新しい分野の極微少ガス分析に 適している.

筆者は現在, 窒素封止の光半導体デバイス抢よび MEMS のヘリウム加圧注入によるリーク検査 $\left(10^{-14} \mathrm{~Pa} \cdot \mathrm{m}^{3} / \mathrm{s}\right.$ 以下 $)$ と超高真空構造材としての銅合金とチタンの比較を, 本封止 RGA ガス放出速度測定法で実施中である．この結果につい ては紙面を替えて別の機会に報告したい。

\section{〔文献〕}

1) Fumio Watanabe: Shinku 48 (2005) 625.

2) Fumio Watanabe: Shinku 48 (2005) 633.

3）真空実験室社で出している TULO-RGA の前モデルでBA 真空 計無しのタイプ. ガス放出・排気作用は文献 4) TULORGA100に同等.

4) 真空実験社製：BA 真空計複合型超低ガス分析計 TULORGA100

5) 米国 Inficon 社 Tware32.

6) F. Watanabe: J. Vac. Sci. Technol. A 22 (2004) 181 and 739.

7) F. Watanabe and N. Kasai: J. Vac. Sci. Technol. A 17 (1999). 